\title{
Wariacja i reguły gry w Stopniach na Parnas*
}

\author{
João Dionísio
}

ORCID: 0000-0002-5211-0290

\begin{abstract}
*Artykuł jest oparty na tekście wygłoszonym na łączonej konferencji Society for Textual Scholarship oraz Association for Documentary Editing (17-20 czerwca, Lincoln, Nebraska). Praca ta nie powstałaby bez pomocy Fundação Luso-Americana para o Desenvolvimento. Dziękuję Catarinie Lourenço i Frederico Lourenço za zgodę na udostępnienie zdjęć rękopisów $\mathrm{z}$ archiwum M.S. Lourenço.
\end{abstract}

W interpretacji literackich manuskryptów, a szczególnie brulionów, wykorzystuje się podejście, które pozwala uniknąć zarówno pułapek drobiazgowych, mało reprezentatywnych mikroanaliz, jak i niebezpiecznych uogólnień opartych wyłącznie na uznaniu operacji pisania (takich jak: rozbudowanie [acretions], usunięcie [deletions], zmiana układu [reorderings]). W celu wyznaczenia drogi pośredniej między tymi dwoma podejściami należy krótko przypomnieć różne sposoby definiowania wariantu powiązanego (connected variant; variante liée). Pojęcie to zostało po raz pierwszy wprowadzone przez Almuth Grésillon na oznaczenie każdego wariantu, który powstaje pod przymusem tekstowych bądź kontekstowych danych i który rodzi potrzebę substytucji Y na $\mathrm{X}^{1}$. W ostatnich latach Grésillon i Jean-Louis Lebrave zaadoptowali bardziej restrykcyjne spojrzenie na zasięg wariantów powiązanych, ustaliwszy, iż powstają one w wyniku językowych ograniczeń (morfologicznych, leksykalnych, syntaktycznych) lub z potrzeby zachowania gramatyki, którą narzuca zastosowanie pierwszego wa-

\footnotetext{
${ }^{1}$ Almuth Grésillon, „Les variantes de manuscrits: critères et degrés de pertinence”, w La publication des manuscrits inédits, red. Louis Hay i Winfried Woesler (Berne: Peter Lang, 1979), 179-189.
} 
riantu. Tym samym warianty niepowiązane byłyby klasyfikowane jako wolne (free variants) ${ }^{2}$. Podejście to zostało zawarte w głównej pracy Grésillon, Éléments de critique génétique ${ }^{3}$, gdzie badaczka definiuje wariant powiązany jako zmianę, która podporządkowuje się językowym ograniczeniom bądź która wprowadza w resztę zdania lingwistyczne konsekwencje zastosowania wolnego wariantu. Wolny wariant jest w tym miejscu każdym śladem poprawki bądź zmiany oprócz tych, które determinują gramatyka, syntaktyka czy ortografia. Choć to podejście niesie pewną heurystyczną wartość na polu językoznawczym, jak zauważył Daniel Ferrer, zdaje się mniej produktywne dla szerszego ujęcia teoretycznego. Dlatego też Ferrer reaktywował podejście samej Grésillon z 1979 roku, kiedy to badaczka utrzymywała, że wolne warianty, ściśle rzecz ujmując, w ogóle nie występują. Co więcej, nawołując do rozszerzenia zasięgu powiązań, Ferrer, zainspirowany teorią gier Wittgensteina ${ }^{4}$, zasugerował bliższe przyjrzenie się strukturze szkicu, by w obrębie tekstowej genezy zaobserwować, jak wygląda wewnętrzna dynamika związków będących przyczyną nowych zmian i ewoluujących z każdą kolejną ${ }^{5}$ Nie ulega wątpliwości, że kiedy Grésillon, Lebrave i Ferrer rozmyślają nad konceptami, takimi jak warianty powiązane, mają na myśli wariację in presentia, tzn. sytuację, w której istnieją dwie (bądź więcej) udokumentowane wersje tekstowe rozważane przez pisarza w początkowej fazie tworzenia. Literacką grę może także sprofilować analiza wariacji in absentia, czyli sytuacji, w której pomimo tego, że zapisana jest tylko jedna wersja tekstowa, krytyk genetyczny może porównać ją z inną, bliższą czytelnikowi. Bywa, że wariacja in absentia jest istotna dla analizy tekstu początkowego per se, ale także dla interpretacji materialnych aspektów procesu pisania (np. zmiana układu na stronie, długopisu, pomocy pisarskich). Obecność wariacji in presentia $\mathrm{i}$ in absentia, w formie wyjaśnionej powyżej, pomoże tym samym rozrysować literacką grę prowadzoną przez pisarza.

Pragnę dowieść, iż wyznaczenie drogi środka w badaniu literackich źródeł zależy od rozpoznania gry, którą można opisać dopiero po zidentyfikowaniu jej reguł - te z kolei da się wyodrębnić po dokładnej analizie jej składników wynikających z tekstu i dokumentu. Oznacza to, że zarówno gry, jak i zasad nią rządzących nie sposób sprecyzować odgórnie, można je uchwycić, czytając tekst i obserwując dokument. Co więcej, gry nie da się poznać w całości, ponieważ nigdy nie jesteśmy w pełni świadomi liczby i natury jej reguł - tym samym odkrycie przez nas zasady wcześniej nieuwzględnianej może zmienić sposób ich postrzegania i w konsekwencji prowadzić do innych wniosków na temat prowadzonej gry.

W celu zilustrowania tego poglądu skupię się na twórczości M.S. Lourenço (1936-2009), wszechstronnego autora i filozofa analitycznego, który przetłumaczył na język portugalski najważniejsze traktaty Wittgensteina i opublikował wiele, znacznie zróżnicowanych pod względem stylu, tomików poetyckich. W tym artykule pragnę zwrócić uwagę na zbiór esejów Os Degraus do Parnaso (Stopnie na Parnas) inspirowany dziełem Gradus ad Parnassum austria-

\footnotetext{
${ }^{2}$ Almuth Grésillon, Jean-Louis Lebrave, „Linguistique et génétique des textes: un décalogue”, w Le français moderne: numéro special. Tendances actuelles de la linguistique française (Paris: CILF, 2008), 37-49, https://tinyurl. com/y2ebqgmt (dostęp: 15.06.2020).

${ }^{3}$ Almuth Grésillon, Éléments de critique génétique. Lire les manuscrits modernes (Paris: PUF, 2016 [1994]), 291.

${ }^{4}$ Zob. ustęp 7 i 33 w: Ludwig Wittgenstein, Dociekania filozoficzne. Przełożył, wstępem poprzedził i przypisami opatrzył Bogusław Wolniewicz (Warszawa: Wydawnictwo Naukowe PWN), 11-12, 27-28.

${ }^{5}$ Daniel Ferrer, Logiques du brouillon. Modèles pour une critique génétique (Paris: Éditions du Seuil, 2011), 169-170.
} 
ckiego kompozytora Johanna Josepha Fuxa (ok. 1660 - luty 1741). U podstaw tych esejów leży podwójna teza głosząca, iż literatura jest sztuką, którą można opanować, a także - skoro język to fakt muzyczny - sztuką, która należy do dziedziny muzyki.

Przywołując ogólny zarys historii publikacji Os Degraus do Parnaso, należy wskazać rok 1989, kiedy Lourenço objął cotygodniową rubrykę w nowo założonej, konserwatywnej gazecie „O Independente”, gdzie zajmował się tak odmiennymi tematami, jak style Wittgensteina, koniec literatury, polityka kulturalna czy też austriacka premiera sztuki Thomasa Bernharda. Opublikował tam także kilka na poły literackich utworów. Dwa lata później zbiór dwudziestu pięciu tekstów zebrano i opublikowano w postaci książki, która otrzymała literacką nagrodę D. Diniz. Lourenço następnie kontynuował pisanie - choć mniej systematycznie - krótkich próz podobnych do tych zebranych w Os Degraus do Parnaso, które najpierw wychodziły w innym magazynie - „Público” i w literackim czasopiśmie „Colóquio-Letras”, a ostatecznie zostały włączone do zmienionego wydania Degraus do Parnaso. Ta nowa (przejrzana, rozszerzona i o zmienionym układzie) wersja została opublikowana w 2002 roku jako „kompletne wydanie tekstu". Obie książkowe edycje, z 1991 i 2002 roku, uznane za niezależne prace weszły w skład literackich dzieł zebranych Lourenço wydanych w roku śmierci pisarza (2009) ${ }^{6}$.

Wśród innych zachowanych dokumentów ważnych dla historii Os Degraus do Parnaso szczególną uwagę należy zwrócić na zbiór odbitek korektorskich pierwszego wydania utworu i, co najważniejsze, na rękopisy wszystkich (oprócz jednego) esejów tego wydania. Szkice te reprezentują najpewniej pierwszy etap procesu tworzenia Os Degraus do Parnaso i można je znaleźć w dwóch notatnikach autora: Harmonielehre (skrót $H$ ) oraz Notizbuch (skrót $N$ ), nazwanych od pierwszych słów naklejek na okładce.

Po tym pobieżnym opisie zbioru esejów, historii ich wydań oraz związanych z nimi dokumentów wróćmy do ujęcia genetycznej interpretacji jako praktyki opartej na identyfikacji gry. Zacznę od dwóch reguł tekstu, których możemy się spodziewać w dziele M.S. Lourenço i sprawdzę, jak względem nich sytuuje się tekst jednego z wymienionych notatników; następnie przejdę do rozpoznania, metodą prób i błędów, reguł dokumentu w drugim notatniku.

Pierwszą zasadę można określić słowami: „Oczekuje się od autora, że będzie pisać po portugalsku”. Ustanawia ją fakt, iż tekst był publikowany w portugalskiej gazecie i adresowany, jeśli nie wyłącznie do Portugalczyków, to do czytelników, którzy są rodzimymi użytkownikami tego języka albo biegle nim władają. Tak się składa, że tę część notatnika $N$, w której znajdują się eseje należące do omawianego zbioru, rozpoczyna strona z tytułem Os Degraus do Parnasso, przy czym ostatnie słowo w języku portugalskim zostaje źle przeliterowane (il. 1).

\footnotetext{
${ }^{6}$ Niektóre eseje rozpowszechnione zostały również w innych językach. Angielski przekład czterech z utworów, pod nazwą Before the Barbarians, znalazł się w wydanej w 1996 roku publikacji A revisionary history of Portuguese literature. Inny tekst przetłumaczony na język niemiecki wyszedł w numerze 353/354 austriackiego czasopisma „Literatur und Kritik”. M.S. Lourenço, „Brennende Schlaflosigkeit in Innsbruck”, tłum. Erwin Koller, Literatur und Kritik 353-354 (2001): 64-68. W 1997 roku Helen Tartar, ówczesna dyrektor ds. wydawniczych Stanford University Press, napisała list do Lourenço z oświadczeniem, że uniwersyteckie Kolegium Redakcyjne zgodziło się opublikować angielski przekład Os Degraus do Parnaso. Po wymianie korespondencji Leland Robert Guyer przygotował wstępne tłumaczenia kilku rozdziałów, ale, najwidoczniej przez zmianę planów wydawniczych Stanford UP, przekład nigdy nie powstał (por. archiwum M.S. Lourenço w Bibliotece Narodowej Portugalii, esp. 62, dok. 394 i 405).
} 


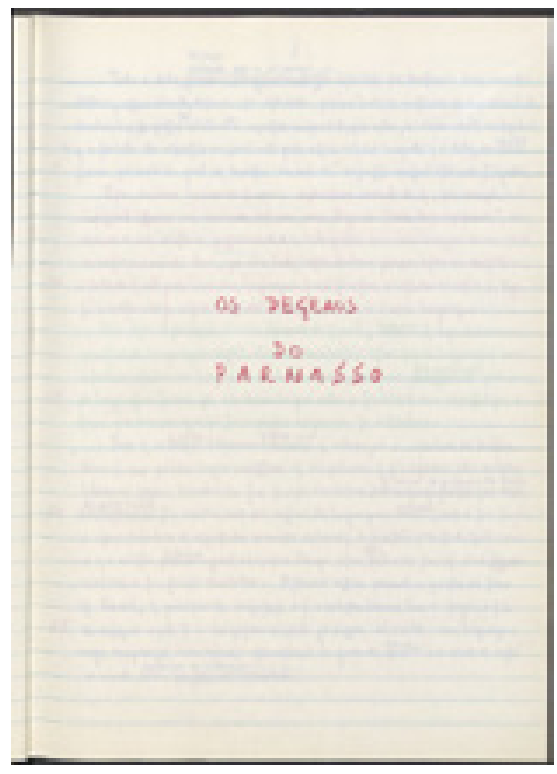

Ilustracja 1. Zeszyt $N$, 36r, tytułowa strona poprzedzająca szkice Os Degraus do Parnaso
Słowo zostało zapisane z podwojonym, a nie pojedynczym $s$, co niesie fonemiczne konsekwencje: pojedyncze $s \mathrm{w}$ pozycji interwokalicznej jest spółgłoską szczelinową dziąsłową dźwięczną, natomiast podwojone interwokaliczne $s$ jest szczelinowe, dziąsłowe i bezdźwięczne. Nie jest to pojedynczy przypadek, w zeszytach $H$ i $N$ występuje konsekwentnie pisownia z podwojonym $s$, podobnie jak w tytule rubryki magazynu, gdzie publikowano eseje - te od pierwszego do dwudziestego drugiego ( $z$ dwudziestu pięciu) zawierają błędny zapis. Ale nawet gdy ukazuje się ostatnia kolumna $\mathrm{z}$ tytułem poprawionym według standardów portugalskiej ortografii, w samym tekście wciąż występuje pisownia z podwojonym $s$ (il. 2 i 3).

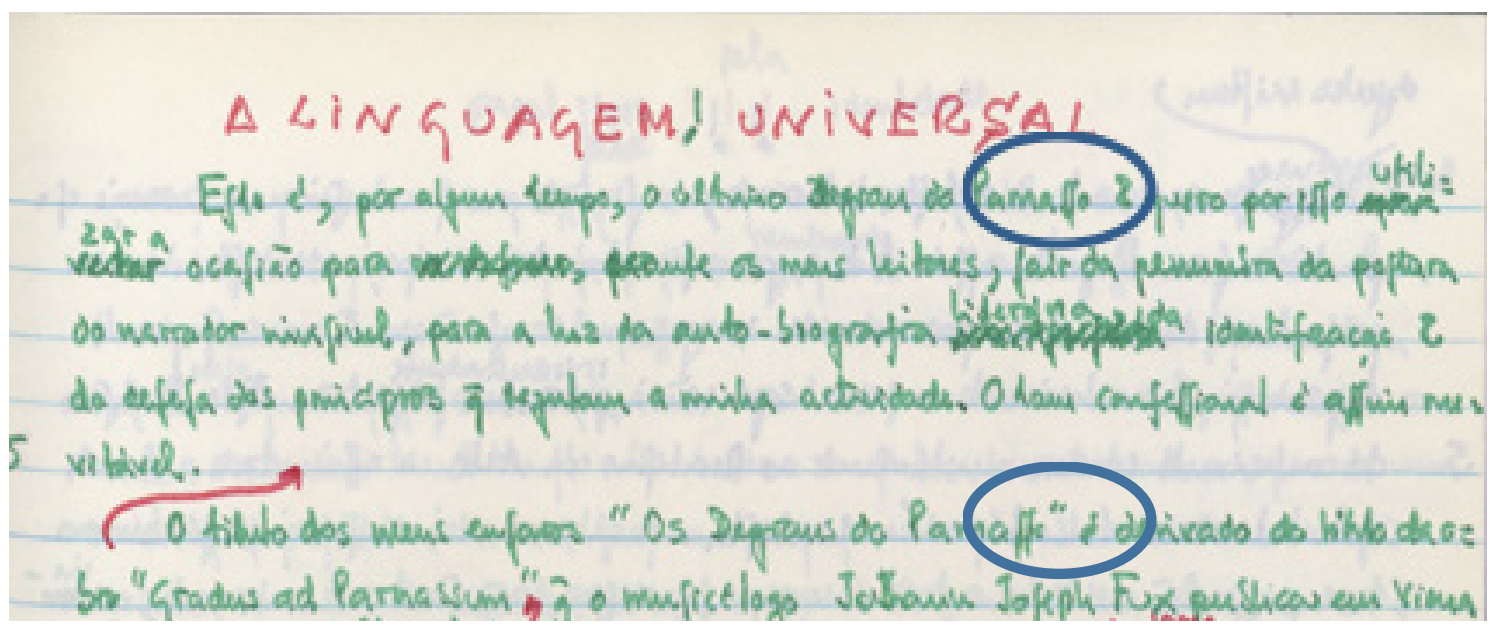

Ilustracja 2. Notatnik $N$, 81r. Szkic ostatniego eseju. Parnaso z podwojonym $s$
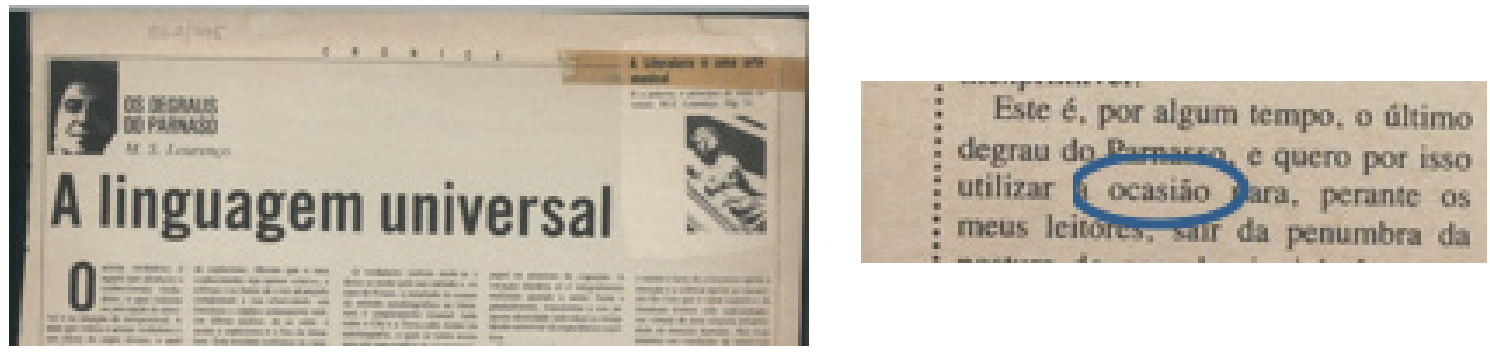

Ilustracja 3. Ostatnia kolumna Os Degraus do Parnaso, z tytułem poprawnie zapisanym, ale w drugim akapicie $s$ w Parnaso jest wciąż podwojone

Korekta pierwszego wydania także potwierdza konflikt pomiędzy obowiązującą ortografią a tym, co wygląda na idiosynkratyczny sposób zapisu (il. 4). 
Este é, por algum tempo, o último degrau do Parhałso, e quero por isso utilizar a ocasiâo para, perante os meus leitores, sair da penumbra da postura do narrador invisível para a luz intensa da autohiografia literária, da identificaçio e defesa dos princípios que regulam a minha actividade cm prosa $\mathrm{e} e \mathrm{em}$ verso. $\mathrm{O}$ tom confessional é assim inevitánel. O título dos meus ensains fOs Degraus do Parnaslol é derivado do título da obra Gradus ad Pamassem, concebida para com-

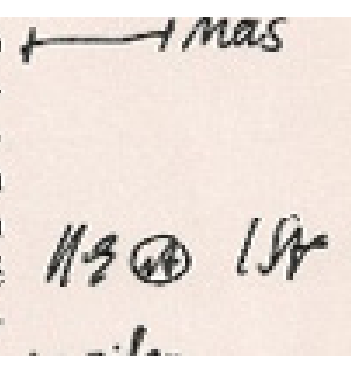

Ilustracja 4. Korekta pierwszego wydania Os Degraus do Parnaso (ostatni esej), z poprawkami podwojonego $s$

Genetyczna (i wydawnicza) interpretacja tego konfliktu jest konieczna do rozpoznania reguł gry, które obowiązują w pisowni. Pozwoli nam to odpowiedzieć na pytanie, jak bardzo portugalski jest język Lourenço, i tym samym doprecyzować zasadę pierwszą: do jakiego stopnia możemy oczekiwać od autora, by pisał po portugalsku? Dokładna analiza obu notatników wskazuje, że błędny zapis tytułu jest tylko jednym z kilku przypadków ortograficznego zamętu. Warto wymienić następujące: w szkicu eseju szóstego pojawia się nebelina $\mathrm{z}$ dodatkowym e zamiast neblina (w znaczeniu 'gęsta para, mgła'), która jest prawdopodobnie wynikiem interferencji z niemieckim słowem Nebel ('mgła, młgawica'); w szkicu eseju trzynastego przeczytać można halucinações rozpoczynające się od $h$, podczas gdy portugalskie słowo to alucinações (wpływ niemieckiego Halluzination bądź angielskiego Hallucination); podobnie w szkicu osiemnastym można natrafić na słowo juxtaposição zapisane z $x$ tak jak w niemieckim i angielskim (juxtaposition), natomiast poprawna forma po portugalsku to justaposição. Oprócz tego także wiele nazw własnych na pierwszy rzut oka wydaje się zniemczonych: nazwisko kanadyjskiego literaturoznawcy Northropa Frye'a (1912-1991) zostaje zamienione na Frey w eseju siedemnastym, natomiast nazwisko rosyjskiego kompozytora Alexandra Scriabina (1871-1915) pojawia się w szkicu dwudziestym jako Skrjabin - bezdźwięczna, zwarta spółgłoska /k/ w portugalskiej ortografii występuje jako $c$, a półsamogłoska /j/ jako $i$ (podobnie w angielskim). W szkicu dwudziestym pierwszym słynny kurort Yalta (Jałta), znany z powojennej konferencji na temat geopolitycznej reorganizacji Europy, pojawia się jako Jalta zgodnie z pisownią niemiecką. Biorąc pod uwagę te informacje, można stwierdzić, iż sposób, w jaki M.S. Lourenço pisze po portugalsku, jest silnie otwarty na inne systemy ortograficzne, przede wszystkim niemiecki. Ślady językowych interferencji tego rodzaju były zmieniane w wydaniach książkowych i czasopiśmiennych zgodnie ze standardami pisowni portugalskiej, ale są one świadectwem czegoś ważniejszego, a nie tylko ciekawym przykładem idiosynkrazji. Wskazują na „odrobinę” tej autorskiej wielojęzyczności, poświadczanej także cechami składni i metadyskursywną leksyką odnoszącą się do sposobu organizacji niektórych esejów, która staje się kluczem do genezy Os Degraus do Parnaso.

Nawiasem mówiąc, M.S. Lourenço jest inspiracją dla postaci w debiutanckiej powieści swojego syna - pierwowzorem ojca narratora o imieniu Nuno. Jeden z fragmentów powieści przedstawia sytuację, w której ojciec spoglądający na restauracyjne menu błędnie odczytuje nazwę przystawki. Danie to, które jest jedną z gastronomicznych specjalności Lizbony (małże gotowane w sosie z oliwy z oliwek, czosnku, kolendry, soli, pieprzu i białego wytrawnego wina), nosi nazwę Bulhão Pato po portugalskim pisarzu (1828-1912) mającym do niego dużą słabość. Choć nazwa przystawki jest dobrze znana w Portugalii, bohater nie rozumie tego, co czyta: 
To menu jest niezrozumiałe... czym będą małże z... co to jest?... Czy będzie to «Burlão Pato»? Gotowane z kaczym mięsem [pato to 'kaczka' po portugalsku]? Nie rozumiem. § Cechą charakterystyczną ojca Nuno było to ogólne wrażenie, które sprawiał, jakby niespełna godzinę temu po raz pierwszy w życiu przybył do Portugalii?.

Przejdźmy teraz do drugiej reguły, która mówi: „Oczekuje się od tekstu, że będzie referencyjny”. W jednym z esejów Degraus do Parnaso odnoszącym się do literackiego i graficznego wątku Salome, Lourenço powołuje się na dzieło, które, ściśle rzecz ujmując, nie istnieje. Ponieważ jednak zostało wydane przez Dover Publications i ponieważ zawiera ilustracje, które znalazły się w angielskiej wersji Salome Oscara Wilde'a, czytelnik jest pewien, że ma do czynienia z pracą The early work of Aubrey Beardsley ze wstępem H.C. Marilliera, opublikowaną przez Dover w Nowym Yorku, w 1967 roku (il. 5).

Mimo naszych oczekiwań co do referencyjności dzieła w notatniku nie zostaje przywołany Aubrey (przez b) Beardsley, ale konsekwentnie Audrey (przed $d$ ) Beardsley. Zgodnie $\mathrm{z}$ tym zarówno $\mathrm{w}$ publikacji $\mathrm{w}$ ga-

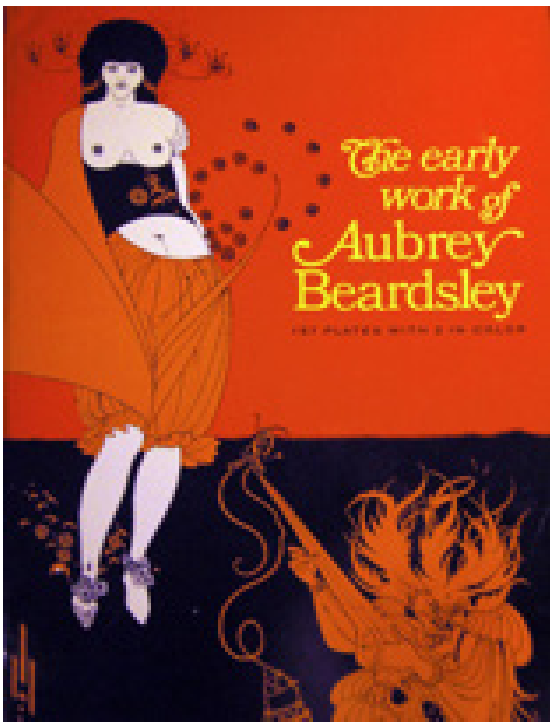

Ilustracja 5. Okładka dzieła The early work of Aubrey Beardsley (wydawnictwo Dover) zecie, jak i w wersji korektorskiej oraz w pierwszym wydaniu pojawia się imię Audrey (rys. 6).

Ilustracja 6. Pierwsze wydanie Os Degraus do Parnaso, s. 41: Aubrey błędnie zapisany jako Audrey

$$
\text { Salomé }
$$

téria sem incorrer em redundâncias. Para definir a Weltanscbautng subjacente, Beardsley faz de Salomé uma leitora do marquês de Sade, de Baudelaire e de Zola, e, mais importante ainda do que a introdução do motivo do hermafroditismo das personagens subordinadas, é a caracterização de Herodias no triunfal desenho cam o número 146 na minha edição Dover de The Early Work of Audrey eardsley, em que a rainha aparece como a mediação entre o homiver e o belo, entre - esboçado homunculus e a perfeição integrada e elegante da jovem hermafrodita, que segura com uma mão uma máscara e com a outra um perfumador.

\footnotetext{
${ }^{7}$ Frederico Lourenço, Pode um desejo imenso (Lisboa: Cotovia, 2002), 99. W oryginale: „- Esta ementa é incompreensível. O que será amêijoas à ... o que é isto?... será „burlão pato”? Será que é confeccionado com carne de pato? Não estou a perceber. § Uma das características do pai do Nuno era a impressão geral, que dele emanava, de que chegara a Portugal pela primeira vez na sua vida há menos de uma hora”. Warto zwrócić uwagę, iż zmiana nazwy „Bulhão” na „Bulrão” może wynikać z dwuetapowego procesu: a) wymowy $h$ w Bulhão w sposób podobny do wymowy niemieckiego $h$ z przydechem, czego konsekwencją jest to, że zamiast zmiękczonej spółgłoski $l$ (w portugalskim wyrażonej dwuznakiem lh) występuje szczelinowa spółgłoska krtaniowa, która, być może użyta karykaturalnie, jest dźwięczna, a nie bezdźwięczna; b) metatezy zamieniającej Bulrão na Burlão.
} 
Nieoczekiwana nazwa własna Audrey mogła pojawić się z wielu powodów. Na przykład w rezultacie dość powszechnej przypadłości odwracania liter $b$ i $d$, którą powoduje pewnego rodzaju problem z kierunkowością czytania, często związany z niektórymi formami dysleksji. Co więcej, podobny przypadek graficznego odwrócenia pojawia się w szkicu dwunastego eseju, gdzie Lourenço zapisuje słowo adoração ('adoracja'), ale wstawia $b$ po inicjalnym $a$, później poprawiając je na $d$ (ilustracja 7). Oczywiście ten jeden przykład nie wystarczy, by wskazać na problemy z kierunkowością jako decydujące o obecności Audreya zamiast Aubreya we wszystkich dokumentach, aż do pierwszego wydania.

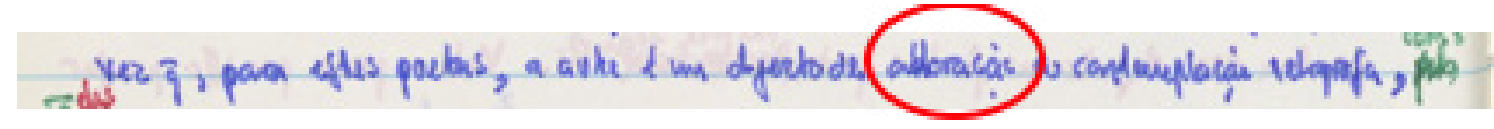

Ilustracja 7. Zeszyt N, 40v, 4. linijka. Zdaje się, że Lourenço zapisał słowo adoração $\mathrm{z}$ dwuznakiem $a b$, poprawiając drugą literę na $d$

Przyczyną tej zmiany może być również banalizacja: mniej powszechne imię - Aubrey - zostaje zastąpione częstszym - Audrey. Istotnie, Aubrey osiąga 57 milionów wyświetleń w wyszukiwarce Google, natomiast Audrey prawie trzy razy więcej ${ }^{8}$, a fakt ten wydaje się zgodny ze zdaniem Martina Westa na temat „tendencji do banalizowania, do spisywania na straty niezwykłej for-

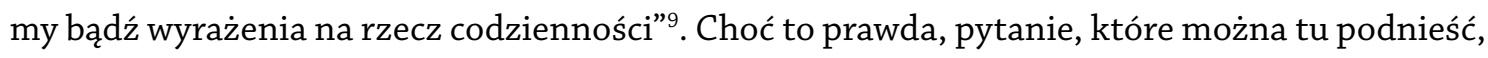
dotyczy tego, dla kogo i w jakich okolicznościach dana forma jest „zwykła”? Z pewnością diagnoza trywialnego banalizowania wydaje się nie na miejscu w wypadku uczonego i pisarza, któremu twórczość Beardsleya jest aż nazbyt dobrze znana. Nie na miejscu byłoby także naruszenie wizerunku (powstałe w wyniku zamiany imion) najsłynniejszej ze wszystkich Audrey, czyli aktorki Audrey Hepburn, przez wmontowanie go w okładkę Salome, chociaż szczupła, koścista twarz postaci u Beardsleya i piękna twarz aktorki nie różnią się znowu tak bardzo (il. 8).

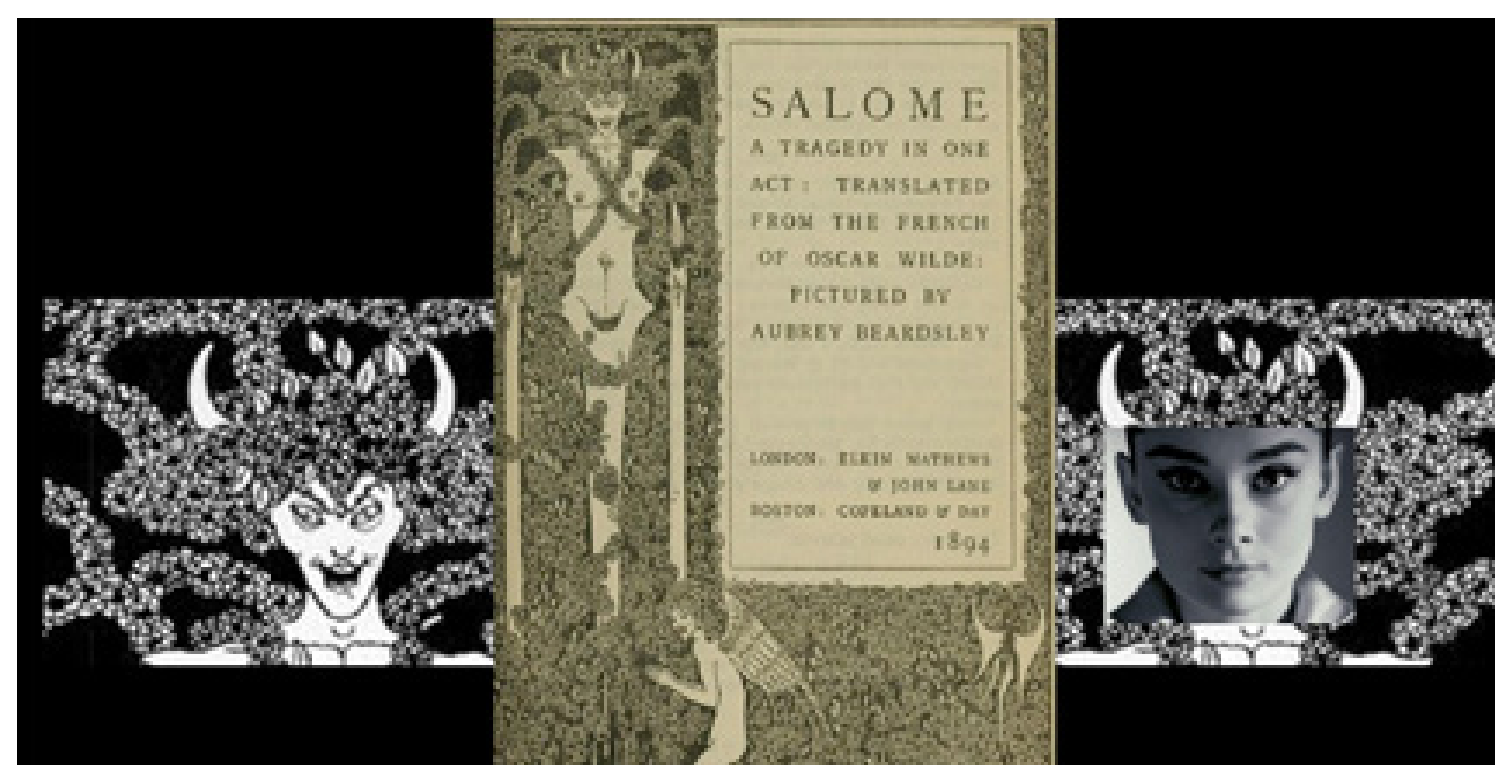

Ilustracja 8. Okładka pierwszego wydania Salome Oscara Wilde’a (angielski przekład) oraz montaż ze zdjęciem Audrey Hepburn zrobionym przez Jacka Cardiffa (1956, zbliżenie)

${ }^{8}$ Dane z 2015 roku. 29 czerwca 2020 roku proporcja nie uległa znacznej zmianie: Aubrey ma 112 milionów odsłon, podczas gdy Audrey osiąga liczbę 269 milionów.

${ }_{9}^{9}$ Martin L. West, Textual Criticism and Editorial Technique Applicable to Greek and Latin texts (Stuttgart: Teubner, 1973), 22. Warto zwrócić uwagę, iż liczba odsłon rzadziej występującego w Google imienia (Aubrey) nie daje podstaw do określenia tej formy jako niezwykłej. 
Trzymając się jednak istoty sprawy, nie można pominąć faktu, że okładka pierwszego wydania Os Degraus do Parnaso będąca pastiszem pierwszego angielskiego wydania Salome przedstawia hermafrodytyczną postać (il. 9 i 10), którą należy wziąć pod uwagę w kontekście płciowej zmiany imienia Beardsleya. Aspekt ten może nam pomóc odpowiedzieć na pytanie o to, w jakim stopniu pisarstwo Lourenço jest istotnie referencyjne, i dopracować zasadę drugą: czy oczekuje się od tekstu, by był w pełni referencyjny? Choć odpowiedź brzmi „tak”, oczekiwania te kolidują z występującymi w tekstach nieścisłościami, które zdają się jednakowoż potwierdzać sympatię Lourenço do takich tematów, jak duchy, sobowtóry i halucynacje.
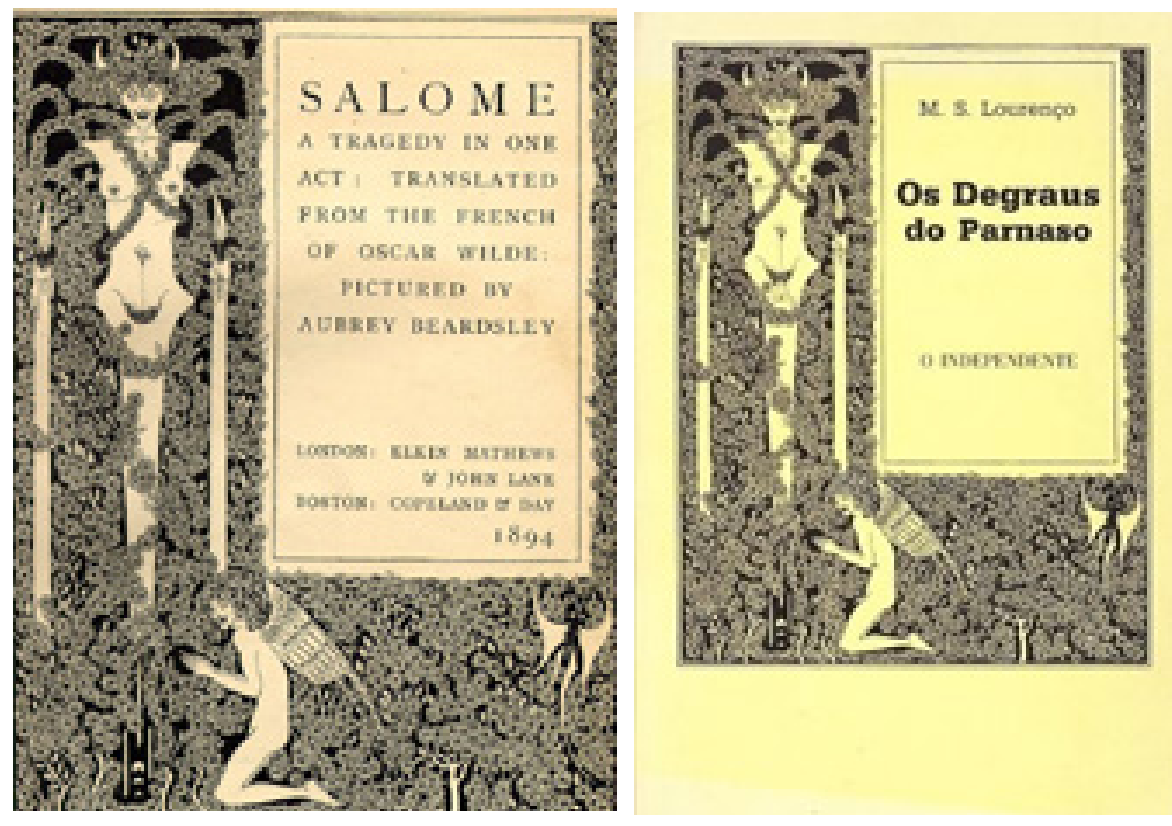

Ilustracje 9 i 10. Okładki Salome Oscara Wilde'a (angielski przekład) oraz Os Degraus do Parnaso M.S. Lourenço (pierwsze wydanie)

Następne reguły są innego rodzaju, ponieważ dotyczą gry w obrębie dokumentu. Jeśli chodzi o tę sferę, nie obowiązuje w niej ani jedna zasada dotycząca gramatyki czy referencyjności, zwłaszcza że nie ma tu żadnych zewnętrznych kryteriów wymuszających na pisarzu podjęcie konkretnych decyzji odnośnie do rozkładu strony, narzędzi pisarskich, sposobów adnotacji itd. Do pewnego stopnia reguły dokumentu, z pewnością silniej niż reguły tekstowe, zależą od indywidualnych zwyczajów pisarza. Biorąc pod uwagę ten aspekt, pragnę najpierw przedstawić charakter notatnika Harmonielehre, na którym od tego momentu zamierzam się skupić.

$H$ to notatnik formatu A4, którego zawartość nie zostaje w pełni oddana przez przyklejoną na okładce naklejkę z napisem: Harmonielehre | III | Skizzen. Powinien liczyć 100 kartek, ale pominąwszy wklejki, pozostaje ich tylko 94. Treść notatnika, na pierwszy rzut oka, złożona jest z trzech części: 1) obserwacje o harmonii w muzyce oraz, równie z tym tematem związane, uwagi dotyczące Stufentheorie (teorii stopni skali); 2) esej filozoficzny Innsbrucker Vortrag, dotyczący natury rozumienia, zapowiedziany słowem Skizzen ('szkice') na naklejce, pierwotnie napisany w języku niemieckim (strony od 1 do 4) i przetłumaczony na angielski od ostatniego akapitu strony czwartej do strony trzydziestej czwartej; 3) wersje pierwszych dziewięciu esejów zawartych w Os Degraus do Parnaso - każda z nich z własną paginacją; pozostałe strony notatnika są niewykorzystane.

Konkretne daty pojawiają się głównie w pierwszej części notatnika, począwszy od 31 grudnia 1983 roku do 3 lutego 1984. Jeśliby przyjąć za prawdopodobne, iż wersje esejów składających się na 
Os Degraus do Parnaso były napisane na krótko przed ich publikacją w gazecie, to ostatnia część notatnika powstała być może pomiędzy 27 stycznia 1989 roku (kiedy pierwszy esej został opublikowany) a jakimś czasem przed 31 marca (kiedy wyszedł ostatni esej z $H$ ).

Nie ulega wątpliwości, że fragment pierwszej części notatnika jest oparty na lekturach drugiego tomu książki Die Musikausbildung Ericha Wolfa zatytułowanego Harmonielehre (por. w szczególności s. 63 i następne). Kopia tej książki znalazła się w bibliotece Lourenço, a obecnie znajduje się na Wydziale Literaturoznawstwa Uniwersytetu Lizbońskiego. Tytułowa strona tego egzemplarza podaje następującą adnotację: „M.S. Lourenço | Innsbruck - 1983”; datę tę można odnieść do faktu korzystania z notatnika pod koniec roku 1983. Nie ulega również wątpliwości, że drugi fragment części pierwszej zawiera spostrzeżenia poczynione po przeczytaniu Harmonielehre Arnolda Schönberga (kopia książki nabytej w 1984 roku także znajduje się w bibliotece Lourenço ${ }^{10}$. Esej filozoficzny w części drugiej natomiast to szkic wykładu na temat mechanistycznych modeli w filozofii świadomości wygłoszonego przez Lourenço w Institut für philosophische Forschung und interdisziplinären Dialog, Innsbruck 1988. Zmieniona wersja tej pracy została wydana jako Modelos mecânicos na filosofia da consciência w numerze szóstym czasopisma „Crítica. Revista do Pensamento Contemporâneo“"11.

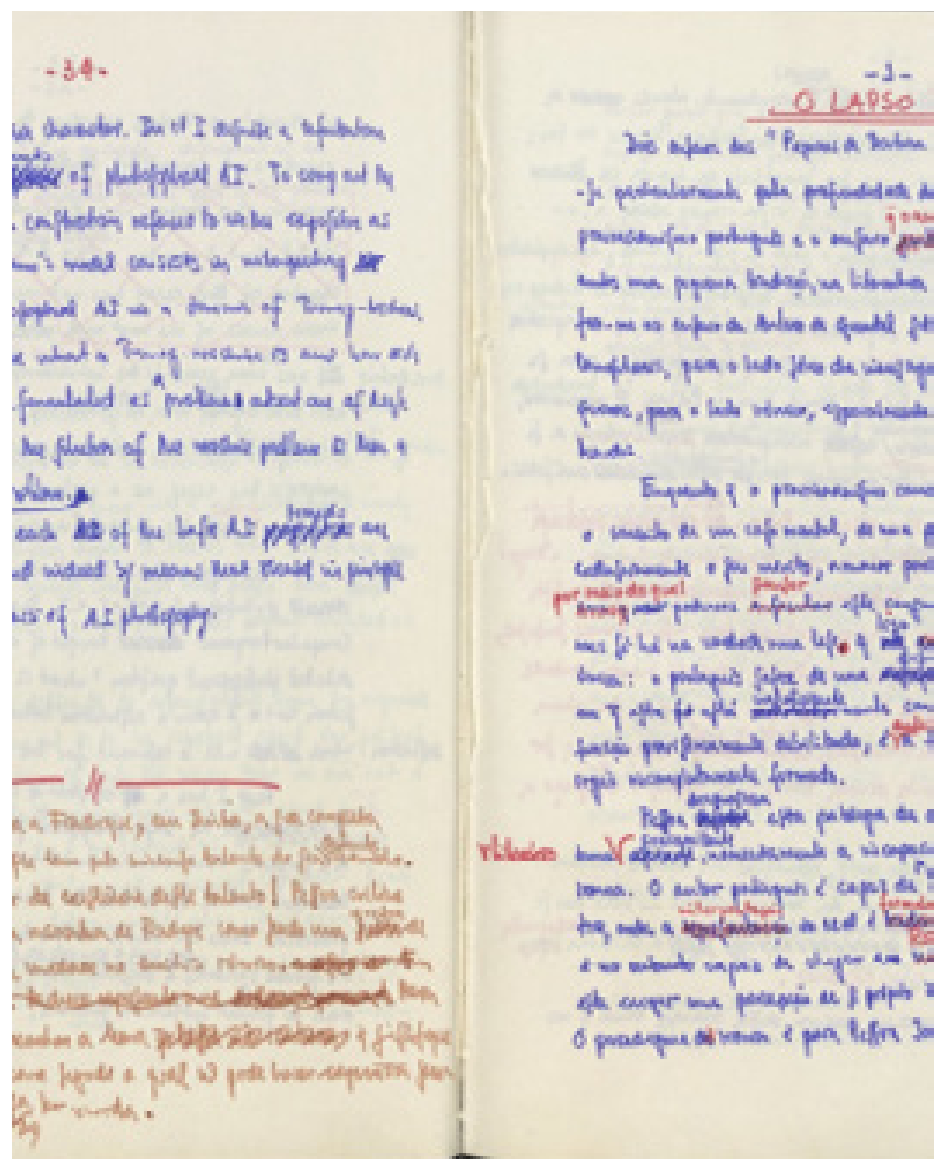

Ilustracja 11.

Notatnik $H$,

skrawki kart

między 56v i $57 \mathrm{r}$

\footnotetext{
${ }^{10}$ Erich Wolf, Die Musikausbildung (Wiesbaden: Breitkopf \& Härtel, 1979) (Biblioteka na Faculdade de Letras da Universidade de Lisboa [Wydział Literaturoznawstwa Uniwersytetu Lizbońskiego], ULFL119584, A 15MSL); Arnold Schönberg, Harmonielehre (Wiedeń: Universal, [1966]) (Biblioteka na Faculdade de Letras da Universidade de Lisboa, ULFL121192, A 72-MSL).

${ }^{11}$ M. S. Lourenço, Modelos mecânicos na filosofia da consciência, „Crítica. Revista do Pensamento Contemporâneo. Wittgenstein, a linguagem e a filosofia”, nr 6 (1991), 49-80.
} 
Szkice umieszczone po eseju filozoficznym w sekcji drugiej notatnika $H$, wchodzące w skład $O s$ Degraus do Parnaso, występują kolejno po sobie w układzie, który od eseju drugiego do dziesiątego odpowiada sekwencji publikacji w gazecie, a później strukturze rozdziałów w pierwszym wydaniu książkowym. W notatniku brak eseju pierwszego z Os Degraus do Parnaso. Należy jednak zaznaczyć, że w miejscu poprzedzającym pierwszy zapisany w notatniku esej, między 56 verso a 57 recto, dostrzec można pozostałości po kilku wyciętych stronach (il. 11). Na podstawie tych skrawków można ustalić, iż cztery kartki zostały usunięte: trzy z nich zawierały pierwszy esej Os Degraus do Parnaso (przeważnie każdy szkic tyle zajmuje), a pozostała kartka prawdopodobnie ogólny tytuł serii (jak w notatniku $N$, f. 36r).

Celowa wydaje się, po pobieżnym opisie notatnika $H$, próba wyróżnienia etapów procesu twórczego, które te teksty przechodziły. Skoro każdy esej, rozpoczynający się zawsze na nieparzystej stronie i zajmujący zwykle pięć stron, był zapisany kolorowymi flamastrami, to obserwacja porządku, w jakim owe kolory po sobie następują, jest kluczowa do uzyskania ogólnego spojrzenia na proces twórczy. Dlatego zasadne jest wymienienie kilku mniej lub bardziej aktualnych cech procesu pisania i wprowadzania zmian do szkiców w notatniku:

1. Niemalże wszystkie narzędzia pisarskie zostały bezrefleksyjnie wykorzystane w procesie pisania i wprowadzania zmian.

2. Kolor pierwszego akapitu jest prawie zawsze niebieski.

3. Każdy kolor użyty na danym etapie pisania stosowany jest przy mniej lub bardziej rozbudowanych sekwencjach tekstowych, zawierających od co najmniej kilku słów do kilku akapitów.

4. W każdej sekwencji zmiany nanoszone są zazwyczaj nie więcej niż dwoma kolorowymi markerami innymi niż te, które zostały użyte do pisania tekstu.

5. Kolor markerów do nanoszenia poprawek jest często taki sam jak kolor użyty do pisania następnych fragmnetów.

6. Jeśli w tej samej sekwencji tekstowej korekta robiona jest przy użyciu dwóch markerów, jeden $z$ nich jest zawsze czerwony.

7. Tytuły, zapisane na czerwono, są zawsze umieszczone na górze pierwszej strony każdego eseju. Na ogół wypełniają one przestrzeń dostępną po zapisie numeru strony i przed pierwszą linią tekstu.

Tych siedem wstępnych obserwacji może służyć jako baza do próbnego rozpoznania reguł, biorąc pod uwagę związek między informacją przestrzenną a zmianami przyrządów piśmienniczych. Im wyraźniej zarysowany związek, tym jesteśmy bliżej rozpoznania reguły; im bardziej rozmyty - tym dalej.

Skoro tytuł znajduje się zawsze na górze nieparzystej strony, przed pierwszym akapitem, i jest zawsze zapisany na czerwono, istnieje - poza regułą dotyczącą umieszczenia - zasada łącząca funkcję tytułu $\mathrm{z}$ kolorem czerwonym.

W odniesieniu do pierwszego akapitu rzecz wygląda inaczej. W ośmiu z dziewięciu esejów akapit ten ma kolor niebieski. Jedyny wyjątek od potencjalnej reguły, która wyznacza kolor niebieski jako przynależny pierwszemu akapitowi, stanowi esej poświęcony Salome - gdzie początkowy ustęp został zapisany czerwonym flamastrem. Niebieski pisak pełni funkcję inicjującą w ramach reguł dokumentu, to znaczy wygląda na arbitralną, mającą znaczenie dla tekstu, decyzję, odstępstwo od tej zasady przy użyciu czerwonego markera 
właśnie w Salome wydaje się motywowane tematyką szkicu. Wystarczy przypomnieć sobie relację Vincenta O'Sullivana na temat genezy sztuki Oscara Wilde'a: po tym, jak Wilde zaczął tworzyć w swojej paryskiej kwaterze, przerwał pisanie, by odwiedzić Grand Café, „gdzie poinformował przewodniczącego orkiestry, "piszę sztukę o kobiecie tańczącej boso w krwi mężczyzny, którego pragnęła i zabiła»"12. Tak minimalistyczny opis sztuki sugeruje, iż miała ona wywołać mocne, barwne wrażenie, skojarzone z kolorem czerwonym. Jeśli założenie to okaże się słuszne, można sformułować regułę dotyczącą wykluczenia bądź wykorzystania koloru innego niż niebieski w pierwszym paragrafie. Mimo iż zasadę można właściwie ująć dopiero po należytym uwzględnieniu dowodów z notatnika $N$, proponuję uwzględnić rozwiązanie $\mathrm{z}$ wykorzystaniem innego koloru: pierwszy akapit jest zawsze niebieski lub w innym kolorze, gdy jest to umotywowane.

Na koniec obserwacja dotycząca etapów procesu pisania i wprowadzania zmian. To trzeci i ostatni przypadek, który tu przywołuję, i jest on najtrudniejszy do uchwycenia, do opisania, a jego analiza, przez wzgląd na liczbę występujących zmiennych, nie prowadzi w prosty sposób do wygenerowania reguły. W przeciwieństwie do pierwszego i drugiego przypadku (tytułu i rozpoczynającego akapitu) mamy tu do czynienia $z$ fragmentem nie w pozycji poprzedzającej tekst główny, ale raczej w pozycji relatywnej: przed i po czymś. I dalej: nie występuje żaden wyraźnie dominujący kolor podobny do niebieskiego w pierwszym akapicie; nie jest ustalona długość, na jakiej obowiązuje poszczególny kolor; przez to, że kolor nanoszenia zmian często pokrywa się z kolorem pisania użytym jeden albo dwa fragmenty niżej, istnieje pewne materialne połączenie pomiędzy dwoma etapami tworzenia, ale nie wiadomo, który z nich będzie pierwszy (nanoszenie zmian na fragment poprzedni czy pisanie następnego fragmentu ${ }^{13}$. Biorąc pod uwagę narzędzie, które w większości wypadków pełni podwójną funkcję: służy zarówno do pisania, jak i do nanoszenia zmian, nie jesteśmy w stanie zdecydować, czy zmiany nanosi się, powiedzmy, zaraz po pierwszej próbie pisania, czy dopiero podczas korekty ${ }^{14}$.

Brak odpowiedzi nie stoi jednak na przeszkodzie, by obserwator mógł dostrzec choć zarys idealnego, powiedzmy, modus scribendi Lourenço: pisarz zapisuje ciąg tekstowy A i poprawia go niezwłocznie; zmienia narzędzie do pisania, koryguje ponownie fragment i zapisuje kolejny ciąg B, poprawiając go niezwłocznie; zmienia narzędzie, koryguje ciąg B i zapisuje $C$, poprawia niezwłocznie itd., itd. Schemat tego działania wyglądałby: A $|\mathrm{ApB}| \mathrm{ApBpC} \mid \mathrm{BpCpD} \ldots$

Dla przykładu w eseju Salome akapit pierwszy na stronie trzeciej zapisany jest jasnozielonym flamastrem z kilkoma naniesionymi na czerwono poprawkami; czerwony jest kolorem następnego akapitu, który kończy się na górze kolejnej strony; niektóre poprawki zostały naniesione innym zielonym markerem, którym zapisano także następny akapit (il. 12).

\footnotetext{
${ }^{12}$ William Tydeman, Steven Price, Wilde. Salome (Cambridge: Cambridge University Press, 1996), 16.

${ }^{13}$ Teraz mamy podstawę do tego, by myśleć, że nanoszenie zmian odbywa się przed pisaniem nowego fragmentu (por. João Dionísio, Carlota Pimenta, The Stages of Composition of Os Degraus do Parnaso, by M.S. Lourenço [w przygotowaniu]).

${ }^{14}$ Wszystko to są pytania bez definitywnych odpowiedzi, podważające podejście oparte na znacznikach, które stara się oddać sprawiedliwość genetycznemu podejściu do procesu pisania.
} 

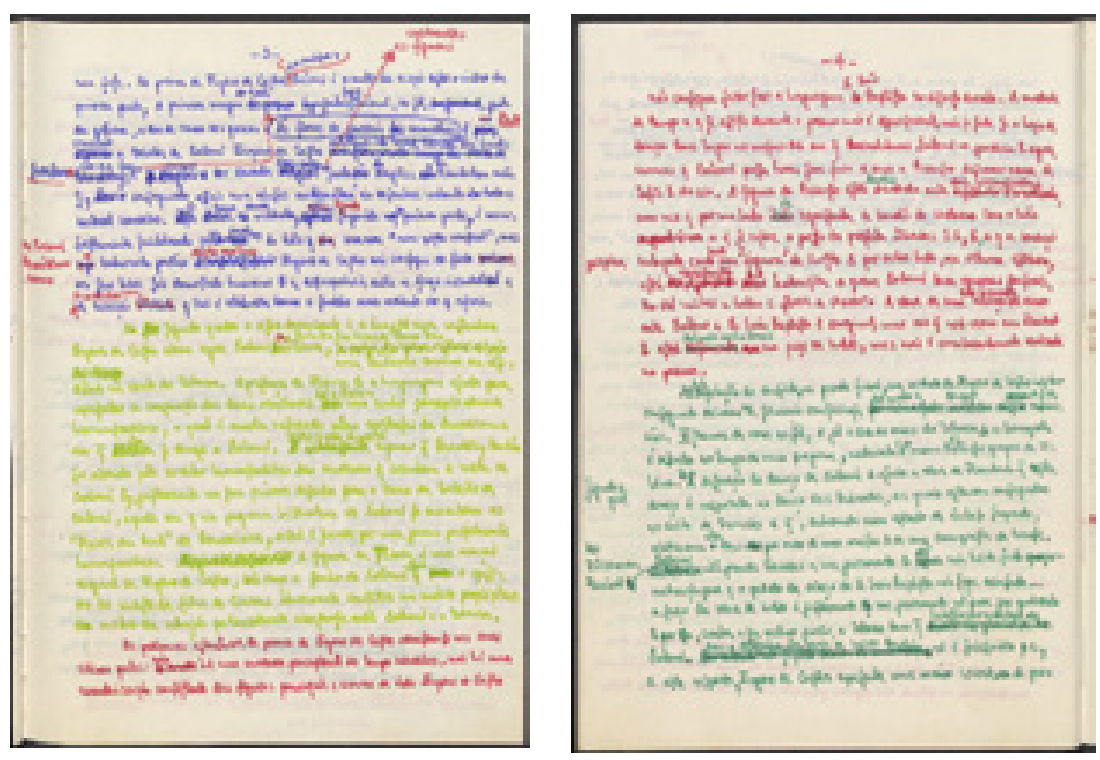

Ilustracja 12.

Notatnik $H$,

$77 \mathrm{r}-77 \mathrm{v}$.

Ta metoda „krok po kroku” wskazuje, iż procesy pisania i nanoszenia zmian następują po sobie zgodnie z rytmem zmiany koloru markerów, a dopełnia je ogólne korygowanie tekstu, które wykonywane jest czerwonym markerem wprowadzającym także tytuł. Co najważniejsze, Lourenço zdaje się tworzyć w trybie stopniowego postępu, „wstępując krok po kroku” - by użyć słów Fuxa ze wstępu do dzieła Gradus ad Parnassum („quâ pedetentim tyrones tanquam per scalam scandere, atque ad artis huius adptionem pervenire possent") ${ }^{15}$.

Podsumowując, choć wariacja in presentia gra ogromną rolę w genetyce tekstowej, to w analizie tekstu rozumianego jako proces nie bez znaczenia będzie szczegółowe badanie słów i fragmentów szkiców, które nie pojawiają się w wersji opublikowanej. Nieścisłości ortograficzne, trywialne błędy są poprawiane w korekcie redaktorskiej, w wyniku której końcowa wersja tekstu przyjmuje kształt zgodny ze standardami ortograficznymi i zasadami przejrzystości tekstu. W wypadku Os Degraus do Parnaso autorstwa Lourenço rezultat takich redakcyjnych standaryzacji powoduje, że zjawiska językowej kontaminacji oraz istotne potknięcia można odkryć jedynie po przejrzeniu ocalałych rękopisów. Dzięki nim czytelnik rozumie materialny wymiar procesu tworzenia, na który składają się użyte przez Lourenço narzędzia do pisania i układ strony stanowiący ramę wstępnych wersji utworu. Sposób, w jaki procesy pisania i wprowadzania zmian wikłają się w teksty tych szkiców, jest analogiczny do pochodzącego z traktatu o harmonii Fuxa stopniowego postępu, który staje się metodą osiągnięcia mistrzostwa w komponowaniu. W świetle powyższego uznanie tekstowych oraz materialnych zmiennych i stałych pozwala na zrozumienie literackiej genezy jako gry, której reguły wymagają ostrożnego rozpoznania.

\section{Przełożyła Izabela Sobczak}

\footnotetext{
${ }^{15}$ Oto jak Fux przedstawia swoją pracę na temat komponowania: „prosta metoda, dzięki której nowicjusz stopniowo, krok po kroku, rozwija się, by osiągnąc mistrzostwo w swej sztuce” (,a simple method by which the novice can progress gradually step by step to attain mastery in this art"; za ang. tłum.: Johann Joseph Fux, The study of counterpoint [z J.J. Fux's Gradus ad Parnassum], wydanie poprawione, tłum Alfred Mann, współpraca John Edmunds (New York, London: W.W. Norton \& Company, 1971), 17.
} 


\section{Bibliografia}

Dionísio, João, Pimenta, Carlota. The Stages of Composition of Os Degraus do Parnaso, by M.S. Lourenço (w przygotowaniu).

Ferrer, Daniel. Logiques du brouillon. Modèles pour une critique génétique. Paris: Éditions du Seuil, 2011.

Fux, Johann Joseph. Gradus ad Parnassum. Texte original intégral. Wprowadzenie, tłumaczenie i przypisy przez Jean-Philippe Navarre. Sprimont: Pierre Mardaga, 2000.

---. The study of counterpoint [z J.J. Fux's Gradus ad Parnassum]. Wydanie poprawione. Przetłumaczone przez Alfred Mann ze współpracą John Edmunds. New York, London: W.W. Norton \& Company, 1971.

Grésillon, Almuth. Éléments de critique génétique. Lire les manuscrits modernes. Paris: PUF, 2016 [1994].

---. „Les variantes de manuscrits: critères et degrés de pertinence". W La publication des manuscrits inédits. Zredagowane przez Louis Hay i Winfried Woesler, 179-189. Berne: Peter Lang, 1979.

Grésillon, Almuth, Lebrave, Jean-Louis. „Linguistique et génétique des textes: un décalogue", 37-49. W Le français moderne: numéro special. Tendances actuelles de la linguistique française. Paris: CILF, 2008, https://tinyurl.com/y2ebqgmt (dostęp: 15.06.2020).

Lourenço, Frederico. Pode um desejo imenso. Lisboa: Cotovia, 2002.

Lourenço, M.S. „Before the Barbarians”. W A Revisionary History of Portuguese Literature. Zredagowany przez Miguel Tamen i Helena C. Buescu, 124-141. New York, London: Garland, 1999.

---. „Brennende Schlaflosigkeit in Innsbruck”. Przetłumaczone przez Erwin Koller. Literatur und Kritik 353-354 (2001): 64-68.

---. Harmonielehre | III | Skizzen. (Notatnik z prywatnej kolekcji). 1983-1989.
---. Modelos mecânicos na filosofia da consciência, „Crítica. Revista do Pensamento Contemporâneo. Wittgenstein, a linguagem e a filosofia”, nr 6 (1991), 49-80.

---. Notizbuch | Ab | Sommersemester 1984. (Notatnik z prywatnej kolekcji). 1984-1989.

---. O Caminho dos Pisões. Lisboa: Assírio \& Alvim, 2009.

---. Rubryka „Os Degraus do Parnaso”. O Independente, 1989.

---. Os Degraus do Parnaso. Lisboa:

O Independente, 1991.

---. Os Degraus do Parnaso. Lisboa: Assírio \& Alvim, 2002.

Tydeman, William, Price, Steven. Wilde. Salome. Cambridge: Cambridge University Press, 1996.

West, Martin L. Textual Criticism and Editorial Technique Applicable to Greek and Latin texts. Stuttgart: Teubner, 1973.

Wittgenstein, Ludwig. Dociekania filozoficzne. Przełożył, wstępem poprzedził i przypisami opatrzył Bogusław Wolniewicz. Warszawa: Wydawnictwo Naukowe PWN, 2000. 


\title{
SEOWA KLUCZOWE:
}

\author{
geneza tekstu
}

wariacja

materialność tekstu

\section{PRZYPADKOWOŚĆ}

\begin{abstract}
AbSTRAKT:
Artykuł, zainspirowany poglądami Daniela Ferrera na genetyczną wariację jako proces zbudowany $z$ wielu powiązań, a nie serię wolnych operacji podporządkowanych innym operacjom, przedstawia literacką genezę jako grę wariacji. Reguły gry można jedynie wstępnie rozpoznać po zidentyfikowaniu jej składników wynikających z tekstu i dokumentu. W artykule szczególną uwagę poświęcam analizie wariacji in absentia, czyli sytuacji, w której choć zapisana jest tylko jedna wersja tekstu, można zestawić ją z wersją, która będzie bliższa czytelnikowi (bądź bardziej oczekiwana). Wariacja in absentia jest istotna dla analizy zarówno tekstowych, jak i materialnych aspektów procesu pisania (np. zmiany układu na stronie, zmiany długopisu, zastąpienia pomocy pisarskich). W artykule śledzę ten rodzaj wariacji na podstawie szkiców Os Degraus do Parnaso (Stopnie na Parnas), kolekcji esejów wszechstronnego pisarza i analitycznego filozofa M.S. Lourenço (1936-2009). Dokładna interpretacja tekstowych oraz materialnych stałych i zmiennych, w zakresie pisowni i użycia narzędzi pisania, prowadzi do wniosku, że przypadki w tekście (elementy, które według W.W. Grega wpływają jedynie na formalną prezentację) nie są zawsze przypadkowe w genezie literackiej.
\end{abstract}

\section{NOTA O AUTORZE:}

João Dionísio - wykładowca na Wydziale Literaturoznawstwa (Uniwersytet Lizboński), gdzie w latach 2010-2013 kierował kursem krytyki tekstu. Pracuje w Centrum Lingwistyki Uniwersytetu Lizbońskiego (CLUL) jako członek grupy filologicznej, a swoje badania koncentruje na nauce o tekście. Przygotował elektroniczne wydanie należącego do kanonu literatury portugalskiej, średniowiecznego dzieła Dobry doradca [Leal Conselheiro] (http://digital.library.wisc.edu/1711.dl/IbrAmerTxt.LealConselIntro), a także opracował trzy tomy krytycznych wydań dzieł Fernando Pessoa (1993, 1997 i 2004). Koordynował inwentaryzację dokumentów M.S. Lourenço (przechowywanych w Bibliotece Narodowej Portugalii). W latach 2013-2016 był prezesem European Society for Textual Scholarship. 